\title{
Critical evaluation of modern concrete applications
}

\author{
Jarostaw Malara ${ }^{1, *}$, and Justyna Szafraniec ${ }^{1}$ \\ ${ }^{1}$ Cracow University of Technology, Faculty of Civil Engineering, Poland, ul. Warszawska 24, \\ 31-155 Cracow, Poland
}

\begin{abstract}
In the article, the modern and innovative applications of concrete mix have been critically analyzed. The authors focused first of all on transparent concrete - LiTraCon. The article mainly analyzed its technical parameters. Another modern way of using the concrete mix, which has been included in the publication, is paving stone absorbed in daylight. This material description is primarily, focused on its serviceability. Another material presented is white concrete, its advantage is the ease of colour choice. The authors also described the possibilities of using properly shaped architectural concrete as well as its unusual use in the form of doors. The entire publication concludes with a summary.
\end{abstract}

\section{Concrete as a building material}

The history of concrete reaches 7000 years BC [1]. The traces of this material were found in the area of present-day Israel. Also in Europe, around 5600 BC, concrete was used in the area of present Serbia. In addition to the Mediterranean basin, traces of the use of this material were discovered in Mexico (around $1100 \mathrm{BC}$ ). The most recognizable traces of the widespread use of concrete are found in Italy and come from antiquity [2].

Increasing the possibility of using concrete and its freeforming have been achieved thanks to the use of steel and later in other components. In the first place, steel bar reinforcement was used to increase the concrete parameters. The next stage was the prestressing of concrete with cables and strings, nowadays various types of fibers are used very intensively, which form scattered reinforcement $[3,4,5]$.

The modern meaning of this material, despite the passage of time from the beginning of its invention, has not lost its value. It is by far the most popular structural material commonly used in cubature, industrial, hydrotechnical or single-family construction. In recent years, the authors of the article have observed an increasing interest of the concrete designers considering concrete as a material both structural and architectural material. The further part of the publication presents, examples of concrete mix application to bring not only the strength parameters of manufactured building elements, but also an attempt to extract the previously unknown beauty of concrete [6].

\footnotetext{
${ }^{*}$ Corresponding author: jmalara@L3.pk.edu.pl
} 


\section{Contemporary examples of concrete use}

\subsection{LiTraCon}

Aron of Losonczi, a Hungarian architect, invented light-transmitting concrete. However, this is not full transparency, but only semipermeability. Generally, this material should be considered a breakthrough and discussed in this article. The name of the concrete LiTraCon is an abbreviation for the words Light Transmitting Conrete [7]. An interesting fact is the possibility of applying sort of this concrete for the production of artistic handicrafts. Elements such as lamps, furniture or sculptures are made of this material.

LiTraCon includes approx $96 \%$ concrete mixture with fine grain size and $4 \%$ fiber optics. The grain size and diameter of the optical fibers have been selected to allow for correct light construction of the finished element structure. Optical fibers are arranged parallel to one another and perpendicular to the edge of a concrete block. This allows for partial light transmission. This means that applying LiTraCon you can see both the shapes and colors of objects on the other side of the material. An example of LiTraCon blocks is presented in Figure 1.

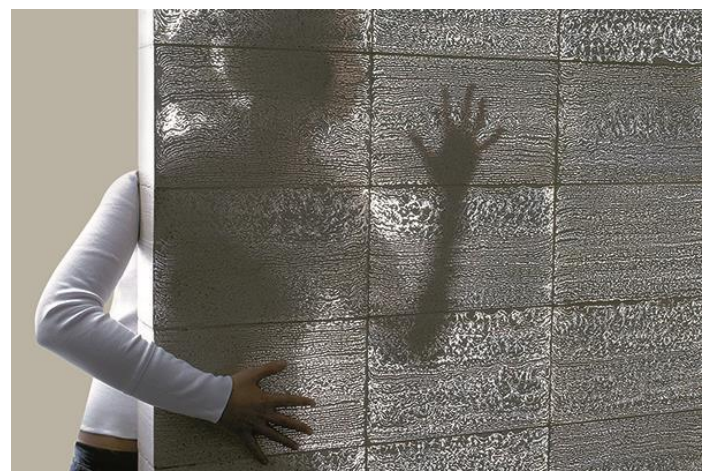

Fig. 1. Photo of LiTraCon's blocks [8].

Turning to the issue of technical parameters, LiTraCon detects the following features:

- density - 2100-2400kg / m3,

- compressive strength - 50MPa,

- bending strength - 7MPa,

- tensile strength - 7MPa,

- composition: about $96 \%$ concrete mix and $4 \%$ optical fibers,

- production form - prefabricated blocks, standard dimensions $600 \times 300 \mathrm{~mm}$

- thickness of blocks - 25-500mm

- available colours - gray, black or white.

A small demand for LiTraCon in Poland is undoubtedly related to the price of this product. The cost of $1 \mathrm{~m} 2$ of $30 \mathrm{~mm}$ thick blocks is estimated at 1300 euros. It should be pointed out that as the thickness of the blocks increases, the price increases considerably. This is due to technological difficulties to provide light transmission for larger element thickness.

Turning to the critical assessment of the innovative solution, among the positives, first of all necessary the architectural value. LiTraCon is a kind of concrete to make the interior of the room more attractive. Technical parameters, especially compressive strength, are high and comparable with high quality concrete, which should also be considered an asset. Despite the theoretical possibility of forming blocks with a thickness of up to $500 \mathrm{~mm}$, without an incredibly large financial outlay, it is difficult to treat LiTraCon as a 
construction material. The prices of elements with a thickness of $30 \mathrm{~mm}$ are already high enough, and thus this element can only be treated as a finishing material or architectural curiosity, which significantly reduces the possibility of its use. In the climatic conditions prevailing in Poland, it cannot be used even as a filling of curtain walls, because in the case of a thermal insulation layer, it would not let light through. In summary, LiTraCon is a very expensive concrete material that can only serve as an architectural feature.

\subsection{Paving stone absorbed in daylight}

The Polish producer of concrete products Polbruk has developed a paving stone enriched with phosphors. Their use allows you to achieve the effect of lighting the sett with a blue light in the darkness. This is due to the ability to absorb solar energy through the phosphors and release it in the form of light at night. This phenomenon is called luminescence. The trade name of the product is Polbruk Lumia. Fig.2 displays the visual effect of phosphor application.

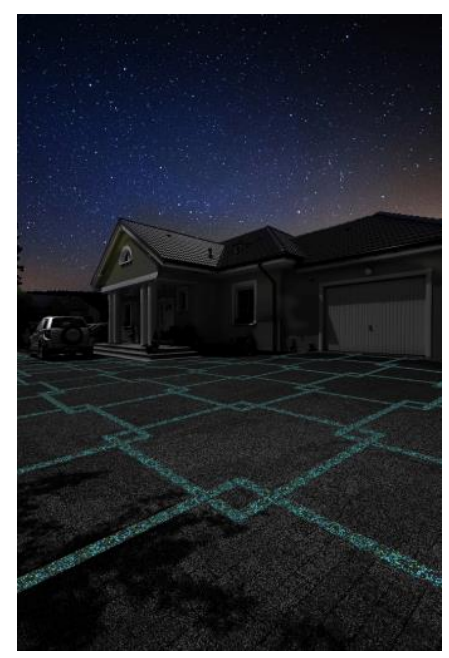

Fig. 2. The possibility of creating patterns with Polbruk Lumia [9].

The use of a shining cube at night SHOWS several major advantages. The first one is the possibility to emphasize horizontal surface markings. Thanks to Polbruk Lumia, pedestrian crossings can be made visible, parking spaces can be marked or lanes can be marked in places where pavement paving or concrete blocks are laid. Another issue is related to energy efficiency. The use of this material does not make it necessary to supply electricity and illuminate key areas for the investor. In addition, the aesthetic value of the concrete block should be emphasized. The characteristic blue light raises the visual dimension of the surface.

On the other hand it should be pointed out that currently the paving stone is produced in three color variants only the shades of gray. Its format is $10 \times 20 \times 6 \mathrm{~cm}$, which makes it difficult to connect it with other concrete cube formats. Afixed thickness of $6 \mathrm{~cm}$ makes it impossible to use it in surfaces intended for heavy car traffic.

According to the authors, the presented solution is an innovative solution on the Polish market. It shows an undoubted advantage over defects, which promises well in the context of a wider application of this product. However, it is necessary to consider expanding the range both in terms of paving stone size and color. Certainly, increasing the universality of the solution will contribute to its widespread use. 


\subsection{White cement}

The search for alternatives to the existing building materials increases investors' interest in concrete products based on white cement. In other to get an imitation of stone slabs with a very similar look, similar strength parameters, but a lower price, this may be the answer. The use of white cement can be found in such elements as:

- terrazzo,

- bricks production,

- plastering mortar,

- element of small architecture (fountains, barbecues, balcony balustrades, etc.),

- plaster,

- architectural concrete,

- glues,

- weld.

While describing white cement, it is necessary to mention its technical parameters. The manufacturing process of white cement is almost identical to the typical gray Portland cement. The difference lies primarily in the selection of appropriate raw materials. The clinker, which is a cement intermediate, is intended to show an appropriate chemical composition and content of individual minerals. The sulfate compounds are very important, in the case of white cement they serve as a regulator of the setting time. Due to a high degree of product fineness and excellent homogenization, the white cement properties are more advantageous than the classic gray cement parameters. The comparison is shown in Table 1.

Table 1. Comparison of exemplary gray and white cements - cement from the Górażdże factory.

\begin{tabular}{|c|c|c|c|}
\hline Technical Parameters & $\begin{array}{c}\text { Portland White } \\
\text { Cement CEM I 42,5 } \\
\text { N }\end{array}$ & $\begin{array}{c}\text { Portland Gray } \\
\text { Cement CEM I 42,5 N }\end{array}$ & Norm [10] \\
\hline $\begin{array}{l}\text { Compressive strength } \\
\text { after } 2 \text { days [MPa] }\end{array}$ & 42,0 & 28,1 & $\begin{array}{c}\geq 20,0 \\
\text { PN-EN 197-1 }\end{array}$ \\
\hline $\begin{array}{l}\text { Compressive strength } \\
\text { after } 28 \text { days [MPa] }\end{array}$ & 67,0 & 59,0 & $\begin{array}{l}\geq 42,5 \leq 62,5 \\
\text { PN-EN } 197-1\end{array}$ \\
\hline $\begin{array}{l}\text { The beginning of } \\
\text { binding time [min] }\end{array}$ & 145 & 188 & $\begin{array}{c}\geq 60,0 \\
\text { PN-EN 197-1 }\end{array}$ \\
\hline $\begin{array}{c}\text { Sulphate content } \mathrm{SO}_{3} \\
{[\%]}\end{array}$ & 2,9 & 2,55 & $\begin{array}{c}\leq 5 \\
\text { PN-EN 197-1 }\end{array}$ \\
\hline Chloride content $\mathrm{Cl}^{-}[\%]$ & 0,01 & 0,065 & $\begin{array}{c}\leq 0,1 \\
\text { PN-EN 197-1 }\end{array}$ \\
\hline Loss of roasting [\%] & 2,5 & 2,39 & $\begin{array}{c}\leq 5,0 \\
\text { PN-EN 197-1 }\end{array}$ \\
\hline $\begin{array}{c}\text { The residue is insoluble } \\
{[\%]}\end{array}$ & 0,2 & 0,67 & $\begin{array}{c}\leq 5,0 \\
\text { PN-EN 197-1 }\end{array}$ \\
\hline
\end{tabular}

More favorable technical parameters of white cements in relation to their gray counterparts have been confirmed many times. The data presented in Table 1 also testify to this. However, due to a higher degree of complexity in the production of white cements as well as the need for even more precise selection of aggregates used for their production, combined with their availability, the price of white cements is about three times higher compared to gray cements. This difference acts upon in the value of the final concrete product.

According to the authors, white cement shows potential that should be conducive to increased use. High technical parameters convince to a positive opinion, but above all, the versatility of applications, combined with aesthetic values. Due to the fact that cement is 
only a component of a concrete mix, its use does not cause large differences in the price of the products obtained.

\subsection{Architectural concrete}

In recent years, architects have begun to appreciate the appearance of natural concrete in a significant way. The concept of architectural concrete has become a common circulation. In the most general terms, architectural concrete should be understood as any kind of surface for which a concrete mix is a finishing layer. Architectural concrete may serve its structural functions too.

Due to a vast definition of architectural concrete, it is difficult to assess this material in terms of chemical composition or the content of individual aggregates or cements. Depending on the desired final effect, the composition of the concrete mix can be individually selected to the needs of the investor. The texture of the concrete surface depends, first of all, on the grain size of the designed mixture. Plasticisers and other fluids are often used to ensure complete filling of molds and boards, depriving finished products of cancers or other imperfections.

The aim of excellent precision and ideal surface in building conditions is difficult to get. That is why architectural concrete products are frequently prefabricated. The prefabrication process allows for making concrete casts in molds, instead of system formworks, this issue significantly affects the visual effects of the obtained element.

A very interesting example of a concrete mix application is a door made of concrete offered by one of the companies. With the exception of the hardware and lock elements, the rest is a concrete mix. Extremely important for this element is the use of dispersed reinforcement, which increases the strength of the door and virtually eliminates the need to preserve them. The example mentioned by the authors is however somewhat abstract. The basic disadvantage in addition to weight is its price. According to catalogs, it ranges between 8,000 and 12,000 euros. It is therefore a unique, but at the same time very luxurious product.

Architectural concrete is an example of a solution that, according to the authors, will certainly be constantly developed in the construction industry. Its advantage is the ability to obtain both design and finishing features in one element. Architectural concrete shows clear trends in contemporary architecture and construction, which often use raw materials emphasizing their natural beauty.

\section{Summary}

The article presents modern examples of the use of concrete mix. According to the examples given by the authors, concrete is currently not only a structural material, but can be a decorative element. The development of construction chemistry and technology has allowed the creation of transparent concrete or shining in the dark absorbed light. Architectural trends caused that the natural beauty of concrete began to be used, without the need to cover it with plaster or other finishing layers.

A natural barrier to using innovative solutions from concrete is their price. In particular, mention should be made of doors made of concrete or light-transmitting LiTraCon blocks. Another issue is fashion in modern construction. Certainly, for some time the material and technological solutions described in this article will no longer be appreciated by designers. However, the objects made with the use of architectural concrete can remain and survive for dozens, or hundreds of years.

The aim of the article, achieved by the authors, was to indicate modern and unusual applications of concrete. Many different products have been analyzed up till now. The most 
interesting ones were presented here. Due to their small scale of application, all these products detected a negative feature of high price. The most important advantage is the aesthetic value. A novel and creative contribution to the development of science, presented in the article, was to find atypical solutions for the use of concrete mix. In addition, the authors made a critical evaluation of the presented technologies. Indicating such applications will contribute to popularizing the use of concrete for less common applications.

\section{References}

1. W. Raczkiewicz, Beton - materiał budowlany znany od wieków (Przegląd Budowlany, 10, 2012)

2. W. Affelt, Dziedzictwo w budownictwie (Wydawnictwo Politechniki Gdańskiej, Gdańsk, 1999)

3. A.M. Brandt, Cement Based Composites: Materials, Mechanical Properties and Performance (Taylor and Francis, London and New York, 2009)

4. W. Sun, Y.M. Zhang, H.D. Yan, R. Mu, Damage and damage resistance of high strength concrete under the action of load and freeze-thaw cycles (Cement and Concrete Research, 29, 1999)

5. T. Zych, Współczesny fibrobeton - możłiwość kształtowania elementów konstrukcyjnych i form architektonicznych (Czasopismo Techniczne, Kraków, 18, 371-386, 2010)

6. M. Głuchowski, Zastosowanie nowoczesnych rozwiązań technologii betonu w kształtowaniu architektury (Czasopismo Techniczne, Kraków, 2010)

7. Anonymous, Translucent concrete developed in Europe. (Civil Engineering : Magazine of the South African Institution of Civil Engineering. Yeoville, 13, 10)

8. http://litracon.hu/en/products/litracon-blokk (visiting at: 02.02.2018)

9. http://www.polbruk.pl/pl/produkty/styl/polbruk-lumia (visiting at: 02.02.2018)

10. PN-EN 197-1:2012 Cement. Część 1: Skład, wymagania i kryteria zgodności dotyczące cementów powszechnego użytku 